\title{
Pola Permukiman Gua Di Pegunungan Kendeng Utara
}

\section{Indah Asikin Nurani}

Keywords: cave, settlement, model, pattern, characteristics, distribution

\section{How to Cite:}

Nurani, I. A. (1999). Pola Permukiman Gua Di Pegunungan Kendeng Utara. Berkala Arkeologi, 19(2), 1-13. https://doi.org/10.30883/jba.v19i2.818

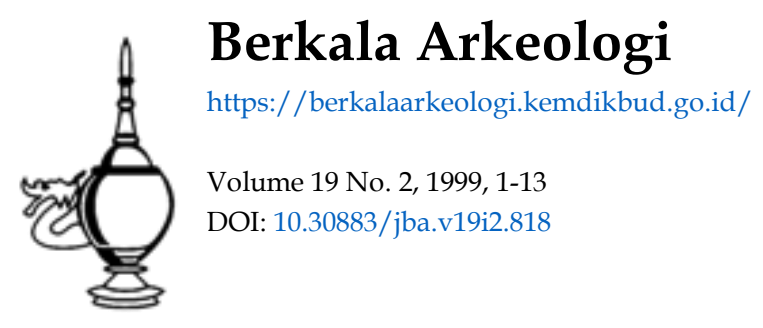

\section{(c) (1) (2)(2)}

This work is licensed under a Creative Commons Attribution-NonCommercial-ShareAlike 4.0 International License. 


\title{
POLA PERMUKIMAN GUA DI PEGUNUNGAN KENDENG UTARA
}

\author{
Indah Asikin Nurani \\ (Balai Arkeologi Yogyakarta)
}

\section{Pendahuluan}

Selama ini penelitian tentang permukiman masih dititikberatkan pada jangkauan penjajagan atau masih bersifat eksploratif. Sehubungan dengan kondisi tersebut, menarik perhatian untuk dikaji lebih mendalam tentang studi permukiman. Terminologi permukiman yang selama ini diketahui meliputi beberapa pengertian antara lain menurut Chang (1968) didefinisikan sebagai cara manusia menata, mengatur, dan menyiasati kehidupannya di muka bumi dalam hubungannya dengan lingkungan fisiografi. Sedangkan menurut Mundardjito (1985) didefinisikan sebagai studi yang memusatkan perhatiannya pada persebaran okupasi, kegiatan manusia, dan hubungan-hubungan di dalam satuan-satuan ruang, untuk memahami sistem teknologi, sistem sosial, dan sistem ideologi dari masyarakat masa lalu.

Berkaitan dengan kajian permukiman, secara periodesasi tampak bahwa sejak masa prasejarah jejak-jejak permukiman mulai tampak, meskipun sifatnya masih semi menetap. Hal tersebut ditunjukan dalam kehidupan manusia saat itu yang masih mengandalkan pada sediaan ekologi untuk mempertahankan hidupnya, dengan menempati gua atau ceruk sebagai tempat tinggal mereka. Mereka menempati gua-gua atau ceruk yang dekat dengan sumber makanan, sehingga apabila lingkungan sekitar tidak lagi menyediakan kebutuhan hidupnya, mereka akan mencari gua-gua atau ceruk pada daerah lain yang masih tersedia sumber makanan yang mereka butuhkan. Berdasarkan pada pola hidup yang masih bergantung pada sediaan ekologi sekitarnya tersebut, maka iklim musiman sangat diperhitungkan. Sementara itu, menurut lan Glover (1982), perpindahan dari daerah kelompok gua satu ke daerah kelompok gua lainnya dalam mencari sumber makanan, tidak serampangan arah perpindahannya. Hal tersebut didasarkan pada data etnografis yang menunjukkan bahwa pemukiman semi menetap ini arah perpindahannya akan melewati kawasan tertentu dengan komunitas yang ada pada daerah-daerah tertentu pada suatu musim. Sementara itu, berdasarkan penelitian yang pernah dilakukan Rogers dan Black (dalam Bettinger, 1980) tentang strategi penghidupan dan pemukiman di antara Weagamow - Ojibwa antara tahun 1880 dan 1910 -di mana saat itu persediaan makanan sangat terbatas pada jenis binatang tertentu-- digambarkan bahwa sistem pemukiman yang digunakan adalah adanya kamp-kamp pangkalan yang dihuni secara berulang-ulang untuk waktu yang lama dan terletak pada pusat areal yang menyediakan sumber makanan yang bervariasi dan lengkap dalam jangka waktu lama, dan "kamp satelit" yang dihuni untuk periode yang lebih pendek dan terletak tidak jauh dari kamp pangkalan untuk 
memperoleh sumber makanan dengan eksploitasi dari sumber-sumber makanan jenis khusus.

Berdasarkan pada asumsi di atas, tampak bahwa dalam pola hidup semi menetap untuk memenuhi kebutuhan hidupnya, manusia saat itu akan menempati suatu daerah tertentu dengan sediaan ekologi yang bervariasi dalam jangka waktu lama dan berpindah pada daerah lain dengan sediaan ekologi yang lebih khusus dalam jangka waktu pendek. Arah perpindahan dari daerah satu ke daerah lainnya tersebut dilakukan secara terarah. Hal tersebut berkaitan dengan kondisi geografis dan potensi ekologi yang berbeda antar kelompok gua dalam suatu musim, sehingga penghunian gua akan menunjukkan jadual hunian sesuai dengan sediaan ekologi yang dipengaruhi oleh musim. Berangkat dari hal itu, maka berikut akan dikaji pola permukiman gua yang terdapat pada Pegunungan Kendeng Utara, di mana terdapat 2 kelompok gua yaitu kelompok gua di Kabupaten Bojonegoro dan kelompok gua di Kabupaten Tuban yang menunjukkan potensi arkeologis yang berbeda baik secara kualitas maupun kuantitas. Permasalahan yang mendasari tulisan ini adalah bagaimana pola adaptasi kedua kelompok gua tersebut dalam memenuhi kebutuhan hidupnya, dan bagaimana peranan kelompok gua satu terhadap kelompok gua lainnya dalam pola permukimannya?

Penelitian gua hunian di Pegunungan Kendeng Utara yang secara administratif terletak di Kabupaten Bojonegoro dan Kabupaten Tuban, pernah dilakukan oleh LJC van Es pada tahun 1926 di Kabupaten Bojonegoro dan oleh Willems di Kabupaten Tuban (Heekeren, 1972). Dalam penelitiannya di Kabupaten Bojonegoro telah berhasil ditemukan lapisan budaya yang tidak begitu tebal di Gua Lawang dan Gua Kramat. Sementara itu penelitian di Kabupaten Tuban yang dilakukan oleh Willems pada gua-gua di Kecamatan Semanding antara lain di Gua Gedeh dan Gua Kandang menghasilkan temuan yang lebih bervariasi dari pada temuan ekskavasi pada gua-gua di Kabupaten Bojonegoro, baik artefak tulang maupun cangkang moluska; sementara itu, produk industri litik kurang menonjol. Secara keseluruhan temuan ekskavasi pada gua-gua di kedua kabupaten tersebut menunjukkan adanya persamaannya dengan temuan di Gua Lawa, Sampung, Ponorogo yang terkenal dengan sebutan budaya Sampung (ciri budaya ini adalah temuan industri tulang).

\section{Gua-gua di Pegunungan Kendeng Utara}

\section{A. Kondisi Geografis}

Secara geomorfologis, daerah Pegunungan Kendeng Utara terbagi atas 3 bagian bentuk lahan yaitu morfologi lahan dataran, morfologi bergelombang lemah, dan morfologi bergelombang sedang. Ketiga morfologi tersebut dibedakan berdasarkan 
persentase lereng. Morfologi dataran mempunyai persentase lereng $0-1.2 \%$. Daerah ini oleh penduduk setempat dimanfaatkan sebagai lahan sawah karena pengairannya berupa bangunan drainage. Sungai-sungai yang melalui daerah ini merupakan sungai kecil berair pada musim penghujan saja dan sedimentasinya sangat tebal. Terdapat beberapa luweng atau sumuran menyebabkan air langsung mengalir masuk ke bawah permukaan. Morfologi bergelombang lemah menempati daerah dengan kemiringan lereng sekitar $2.5-3.2 \%$ berupa bukit-bukit kecil karst. Umumnya lembah berbentuk "V" sampai dengan " $U$ " dengan pola aliran dendritik seperti cabang pohon dan masih cukup jelas pola alirannya. Sungai-sungai yang mengalir, sebagian berair musiman tetapi ada pula yang berair sepanjang tahun. Sungai ini mengalir di atas permukaan dari hulu daerah yang lebih tinggi tetapi ada pula air muncul dari gua-gua sebagai foklus. Lembah-lembah antar bukit karst berpola "U" sebagai sungai purba dan sedimentasi tanah yang cukup tebal oleh penduduk setempat dipergunakan untuk perladangan. Sedangkan morfologi bergelombang sedang menempati daerah kemiringan lereng 7.3 - 8.6\%. Lembah-lembah berada antara bukit karst yang berbentuk "V" dengan pola aliran multi basinal yaitu sungai-sungai yang mengalir tidak menerus hilang pada suatu tempat dan muncul kembali di tempat yang lain. Lubang tempat masuknya air disebut ponor dan banyak terdapat pada daerah morfologi bergelombang sedang dengan litologi batugamping. Sedangkan lobang tempat keluarnya air disebut foklus yang biasanya berupa gua. Daerah ini oleh penduduk setempat dipergunakan sebagai hutan jati. Sungai berair hanya pada musim penghujan saja dan biasanya hilang pada lobang ponor atau sumuran. Stadia erosinya sedang sehingga membawa material yang cukup banyak ke daerah yang lebih rendah.

Berdasarkan hasil survei yang telah dilakukan oleh Balai Arkeologi Yogyakarta, kawasan Pegunungan Kendeng Utara ini memiliki beberapa tipe gua yaitu tipe gua, ceruk dan sumuran atau luweng (Bahasa Jawa). Ketiga tipe gua tersebut tidak seluruhnya layak huni. Kelayakan gua hunian didasarkan pada tiga hal yaitu dekat dengan sumber air, tersedianya sumber makanan, dan tata letak gua. Di antara ketiga tipe gua tersebut, tipe gua cenderung memiliki indikasi hunian, selain itu beberapa tipe ceruk memiliki indikasi hunian juga, sedangkan tipe sumuran sama sekali tidak menunjukkan indikasi hunian. Tipe sumuran merupakan sumber mata air atau sungai bawah tanah.

\section{B. Kabupaten Bojonegoro}

Berdasarkan pada survei permukaan yang dilakukan tim penelitian Balai Arkeologi Yogyakarta secara eksploratif gua-gua yang terdapat di Kabupaten Bojonegoro sebanyak 16 buah gua dengan 3 tipe yaitu 6 buah tipe gua (cave), 4 buah ceruk (rock shelter), dan 6 buah sumuran atau sungai bawah permukaan tanah (dwelling). Persebaran gua tersebut memusat pada kawasan perhutani jati yang secara 
administratif terletak pada 2 kecamatan yaitu Kecamatan Dander dan Kecamatan Bubulan (gambar 2). Pada Kecamatan Dander terdapat 6 sumuran, 2 ceruk, dan 5 gua, sedangkan Kecamatan Bubulan terdapat 1 gua dan 2 ceruk. Selanjutnya untuk mengetahui lebih lanjut pola pemanfaatan lahan gua hunian, maka dilakukan ekskavasi pada 4 buah gua. Berikut hasil dari keempat gua yang diekskavasi (Nurani , 1998/1999).

\section{Gua Pawon}

Perolehan data ekskavasi di Gua Pawon dengan membuka 5 buah kotak berukuran 1.5 m x 1.5 m, yaitu kotak B-7, D-10, E-8, G-5, dan I-10 adalah sebagai berikut. Kotak D10 dan I-10 ditemukan 4 layer yang terdiri atas lapisan 1 merupakan lapisan top soil yaitu lapisan tanah urugan (sedimentasi tanah resen) tanpa temuan, lapisan dua berupa lempung pasiran warna coklat kekuningan dengan temuan berupa fragmen tulang dan gigi binatang vertebrata (Cervidae dan Bovidae), khusus untuk kotak D-10, pada lapisan ini ditemukan artefak tulang beripa fragmen spatula, calon lancipan, dan alat pengasah masing-masing sebuah, lapisan 3 merupakan lapisan sisipan berupa lapisan lempung berwarna abu-abu kekuningan dengan temuan berupa fragmen tulang dan gigi binatang vertebrata, sedangkan lapisan 4 berupa lapisan lempung pasiran berwarna coklat kehitamạn dengan temuan berupa fragmen tulang dan gigi binatang vertebrata.

Hasil ekskavasi pada Kotak E-8 sangat berbeda dengan temuan pada kotak D-10. Kotak E-8 menunjukkan adanya 4 lapisan --sama dengan lapisan pada kotak D-10-namun posisi lapisan tidak merata pada seluruh kotak. Penggalian sampai pada kedalaman $110 \mathrm{~cm}$ dari permukaan tanah tidak terdapat temuan penting, bahkan ditemukan plastik dan bungkus rokok masa sekarang pada kedalaman $50 \mathrm{~cm}$ dari permukaan tanah, yang menunjukkan bahwa lapisan tanah pada kotak E-8 ini sudah terganggu. Temuan pada kotak ini berupa sisa-sisa binatang vertebrata berupa fragmen tulang dan gigi yang ditemukan mulai pada spit 12 sampai pada spit 14 (akhir penggalian).

Pada kotak G-5 ini ditemukan 2 lapisan tanah dimana kondisi lapisan tanah dan temuannya sama dengan kotak D-10. Lapisan 1 merupakan lapisan top soil tanpa temuan sedangkan lapisan 2 merupakan lapisan lempung pasiran berwarna coklat kekuningan dengan kandungan temuan berupa sebuah artefak tulang, dan sisa-sisa binatang vertebrata berupa fragmen tulang dan gigi.

Sejarah terbentuknya lapisan stratigrafi pada Gua Pawon sejumlah empat lapisan tanah menunjukkan adanya faktor alam yang mempengaruhinya, sehingga kondisi tanah pada masing-masing kotak menunjukkan gradasi yang berbeda. Hal tersebut tampak pada kotak E-8 yang berada pada lahan di bawah atap gua yang berlobang. Selain itu pengamatan lajur longitudinal yaitu kotak D-10; E-8; dan G-5 menunjukkan temuan 
artefaktual terdapat di kotak D-10 (terdepan) dan G-5 (terbelakang), sementara kotak E-8 (tengah-tengah) tidak ditemukan artefaktual. Kondisi tersebut dapat disimpulkan kotak E-8 mengalami proses sedimentasi yang berbeda dengan kedua kotak lainnya, sehingga kenampakan stratigrafi secara lengkap hanya ditemukan pada sebagian dinding selatan dan dinding barat, sementara itu bagian lainnya hanya terdapat dua lapisan tanah (lapisan 1 dan 4).

\section{Gua Gampeng}

Gua Gampeng dilakukan pembukaan dua kotak lubang uji yaitu LU-1 dengan kedalaman akhir 150 meter dari SDP (10 cm di atas permukaan tanah yang paling tinggi) dan LU-2 dengan kedalaman akhir $90 \mathrm{~cm}$ dari SDP. Dari penggalian kedua kotak tersebut menghasilkan dua lapisan tanah terdiri atas lapisan humus dan lapisan pasir lempungan. Tebal lapisan humus antara 2 sampai $10 \mathrm{~cm}$, tanpa menghasilkan temuan. Tebal lapisan pasir lempungan pada LU-1 antara 134 -- 138, sedangkan LU-2 setebal antara $65-75 \mathrm{~cm}$. Kandungan temuan pada lapisan kedua ini, untuk LU-1 berhasil ditemukan uang kepeng dua buah, komponen manusia berupa gigi prageraham sebuah, beberapa fragmen gerabah, dan sebuah fragmen artefak batu dari rijang. Selain itu pada kotak LU-1 ditemukan pula fragmen tulang vertebrata dan cangkang moluska air laut dan air tawar. Temuan yang menarik pada kotak LU-1 adalah temuan gigi ikan hiu, sebab jarak laut dengan daerah ini sejauh $50 \mathrm{~km}$. Sementara itu, temuan yang berhasil dikumpulkan pada kotak LU-2 meliputi sebuah gigi seri manusia, beberapa fragmen gerabah, tulang vertebrata, dan cangkang moluska.

\section{Gua Payung}

Penggalian di gua ini dilakukan dengan membuka dua kotak yaitu LU-1 dengan kedalaman akhir $150 \mathrm{~cm}$ dari SDP ( $10 \mathrm{~cm}$ di atas permukaan tanah tertinggi) dan LU2 dengan kedalaman akhir $120 \mathrm{~cm}$ dari SDP $(10 \mathrm{~cm}$ di atas permukaan tanah tertinggi). Dari hasil penggalian tersebut terlihat adanya perbedaan lapisan antara kedua kotak. Pada kotak LU-1 terdiri atas 3 lapisan, sedangkan kotak LU-2 hanya 2 lapisan. Hal tersebut disebabkan lapisan 2 LU-1 merupakan lapisan runtuhan atap gua, sementara pada LU-2 runtuhan gua tersebut tidak tampak. Ketiga lapisan tersebut terdiri atas tanah pasir halus, tanah pasir lempungan, dan tanah lempung pasiran.

Lapisan pertama (tanah pasir halus) memiliki ketebalan antara $2-8 \mathrm{~cm}$ pada $\mathrm{LU}-1$, dan setebal 3 -- 15 pada LU-2. Kandungan temuan LU-1 pada lapisan ini didominasi oleh fragmen gerabah baik yang sudah diglasir maupun belum, dan beberapa ada yang berhias. Sedangkan temuan pada LU-2 berupa fragmen tulang binatang vertebrata. Lapisan 2 yaitu lapisan tanah pasir lempungan hanya ada pada LU-1 yaitu lapisan berupa runtuhan atap gua setebal $15-30 \mathrm{~cm}$, dan tidak mengandung temuan. Sedangkan lapisan ketiga berupa lapisan tanah lempung pasiran (di mana untuk LU-2 
merupakan lapisan kedua) memiliki ketebalan 80 -- 110 pada pada LU-1, dan setebal 90 -- $110 \mathrm{~cm}$ pada LU-2. Lapisan ketiga ini untuk LU-1 tidak terdapat temuan, sementara pada LU-2 berhasil ditemukan beberapa temuan yang bervariasi antara lain berupa artefak dari cangkang moluska sejumlah \pm 5 buah, sebuah fragmen gerabah berhias leter S, artefak dari tulang sekitar 3 buah, sebuah gigi geraham manusia, fragmen tulang vertebrata, dan beberapa fragmen cangkang moluska.

\section{Gua Grajen}

Pembukaan kotak lubang uji di Gua Grajen hanya sebuah yaitu LU-1 yang mencapai kedalaman akhir $160 \mathrm{~cm}$ dari SDP (10 $\mathrm{cm}$ di atas permukaan tanah tertinggi). Dari hasil penggalian tersebut tersingkap dua stratigrafi yang terdiri atas lapisan pertama berupa tanah humus dan lapisan kedua berupa tanah lempung pasiran. Lapisan pertama memiliki ketebalan antara $6-20 \mathrm{~cm}$ tanpa temuan, sedangkan lapisan kedua setebal antara $110-130 \mathrm{~cm}$ dengan beberapa temuan yang berhasil dikumpulkan antara lain berupa fragmen tulang binatang vertebrata, cangkang moluska, fragmen gerabah, dan sebuah artefak batu (serut) dari rijang.

\section{Kabupaten Tuban}

Berdasarkan survei permukaan secara eksploratif gua-gua yang terdapat di Kabupaten Tuban berjumlah 30 buah (gambar 1) yang terdiri atas 3 tipe gua, ceruk, dan sumuran. Ketigapuluh gua tersebut terletak pada 6 kecamatan, yaitu Kecamatan Semanding sebanyak 11 buah, Kecamatan Montong 3 buah, Kecamatan Plumpang 2 buah, Kecamatan Rengel 5 buah, Kecamatan Kerek 6 buah, dan Kecamatan Palang 3 buah (Jatmiko, 1996). Sebagaimana di Kabupaten Bojonegoro, di Kabupaten Tuban juga sebagian besar gua tersebut bertipe sumuran. Sedangkan secara arkeologis, temuan artefak dan ekofak pada gua-gua di Tuban menunjukkan temuan yang lebih bervariasi dibandingkan di Bojonegoro. Berdasarkan pada survei permukaan, selanjutnya dilakukan ekskavasi pada beberapa gua yang dianggap memiliki indikasi hunian yaitu meliputi Song Prahu (Nitihaminoto, 1980), dan Gua Peturon (Jatmiko, 1997). Berikut adalah hasil ekskavasi pada kedua gua tersebut.

\section{Gua (Song) Prahu}

Hasil ekskavasi pada Gua Prahu ini meliputi sejumlah alat tulang berupa 3 buah lancipan, sebuah pisau, 4 buah pahat, dan 6 buah mata panah; alat dari cangkang moluska berupa serut dan sudip; alat litik berupa mata panah dan serpih; selain itu juga ditemukan komponen manusia dan sisa binatang vertebrata. Pada lapisan atas terdapat kereweng berhias dan polos (Nitihaminoto, 1980). 


\section{Gua Peturon}

Gua Peturan merupakan sebuah gua yang mempunyai lorong tidak begitu dalam serta di bagian depan (pintu masuk)-nya banyak terdapat ceruk yang menonjol. Gua ini berada pada titik ketinggian $90 \mathrm{~m}$ dari permukaan laut dan berjarak $12 \mathrm{~km}$ dari garis pantai terdekat (arah utara pantai Tuban). Pintu masuk gua menghadap ke arah selatan dengan ukuran lebar $16 \mathrm{~m}$ tinggi $6 \mathrm{~m}$. ruangan dalam gua $48 \times 47 \times 5 \mathrm{~m}$.

Stratigrafi ekskavasi Gua Peturon

Lapisan A adalah lapisan teratas yang merupakan tanah teraduk setebal $30 \mathrm{~cm}$ dengan kandungan temuan berupa fragmen sisa-sisa hewan dan cangkang moluska sangat melimpah bercampur dengan bok-blok batuan gua.

Lapisan B adalah lapisan kedua berupa lempung coklat muda bercampur batugamping setebal $60 \mathrm{~cm}$ dengan kandungan temuan fragmen sisa-sisa hewan dan moluska serta sebagian kecil kereweng dan alat-alat serpih

Lapisan $\mathrm{C}$ merupakan lapisan ketiga berupa lempung coklat tua bersifat kompak dan padat bercampur blok-blok gamping setebal $35 \mathrm{~cm}$ dengan kandungan temuan sisasisa fragmen tulang fauna dan cangkang moluska serta alat-alat serpih yang sudah tersementasi dalam jumlah yang semakin berkurang.

Temuan artefaktual pada gua ini meliputi temuan alat batu, alat tulang, dan alat cangkang moluska. Alat litik meliputi temuan alat serpih (6 buah serpih dengan retus, 37 buah serpih tanpa retus, sebuah serpih besar, dan serpihan/debris sebanyak 53 buah), sebuah alat bilah, 6 buah alat serut (serut ujung dan serut samping masingmasing 2 buah dan serut cekung dan serut gigir masing-masing sebuah), sebuah gurdi (borer), sebuah lancipan, sebuah mata panah, 4 buah batu inti, dan 2 buah batu pukul. Sedangkan alat tulang berupa spatula dan lancipan masing-masing sebuah, dan alat serut dari cangkang moluska (Jatmiko, 1997).

\section{Pengaruh Faktor Alam dalam Pola Hunian}

Melihat kondisi riil potensi arkeologis pada kedua kelompok gua di Kabupaten Bojonegoro dan Kabupaten Tuban menunjukkan adanya perbedaan yang menyolok. Hal tersebut dapat diketahui dari temuan hasil ekskavasi yang menunjukkan bahwa gua-gua di Kabupaten Bojonegoro minim temuan artefaktual, sedangkan temuan artefaktual hasil ekskavasi pada gua-gua di Kabupaten Tuban sangat bervariasi baik artefak batu, tulang, maupun cangkang moluska. Sementara itu, secara geografis, kedua kabupaten tersebut sedikit berbeda. Hal tersebut ditunjukkan pada potensi vegetasi yang relatif homogen di Kabupaten Bojonegoro, sedangkan di Kabupaten Tuban menunjukkan vegetasi yang heterogen. Selain itu, dari morfologi lahan daerah Bojonegoro sebagian besar termasuk morfologi relatif datar sampai bergelombang 
lemah dengan lembah berbentuk $U$, sehingga kondisi kelembaban relatif tinggi. Kondisi geografis yang cenderung berbentuk U tersebut menunjukkan bahwa tingkat vegetasi dan sumber hidup minim atau tidak bervariasi. Selain itu dataran aluvial sebagaimana daerah Bojonegoro menunjukkan daerah dengan kecenderungan lembab dan tidak nyaman untuk hunian dalam jangka waktu lama. Sementara itu di daerah Tuban morfologi lahannya relatif terjal dengan lembah bentuk $\mathrm{V}$, di mana sediaan ekologi lebih bervariasi dan melimpah baik flora maupun fauna darat dan laut dalam jangka panjang.

Dalam pembentukan lapisan tanah, suatu lingkungan merupakan proses tersedimentasinya suatu material lepas oleh media tertentu yang dipengaruhi oleh kondisi kimiawi, fisika, dan biologis secara alamiah dan terendapkan pada suatu tempat sehingga membentuk lapisan stratigrafi. Kondisi kimiawi mempengaruhi saat terjadinya penguraian unsur-unsur kimia dalam oksidasi, reduksi, dan replacemen membentuk satuan material yang baru. Faktor fisika juga mempengaruhi proses sedimentasi dan pengendapan berupa banyak sedikitnya material yang dibawa, besar kecilnya energi, besar kecilnya ukuran butir material yang diendapkan, dalam dangkalnya lingkungan pengendapan, sifat arus media pembawa, dan cepat lambatnya pengendapan. Sedangkan kondisi biologis yaitu pengaruh dari tumbuhan, hewan, dan manusia. Berdasarkan hal itu, dan melihat pembentukan stratigrafi pada gua-gua yang telah diekskavasi di Kabupaten Bojonegoro, menunjukkan bahwa proses sedimentasi yang terjadi dipengaruhi pula oleh faktor kimiawi, fisika, dan biologis secara alamiah. Hal tersebut ditunjukkan pada lingkungan geografis yang berada di lembah berbentuk "U" yang mengandung endapan aluvial yang tebal beriklim tropis musiman dengan tumbuhan di sekitarnya yang homogen.

Kondisi geografis demikian sangat berpengaruh dalam pola hunian manusia saat itu yang sangat bergantung pada potensi ekologi sekitarnya. Dalam mempertahankan hidupnya, manusia akan selalu memilih satuan lahan yang nyaman dan tidak terganggu oleh gangguan alam seperti genangan banjir dan pasang laut untuk bertempat tinggal sebagai wadah bagi semua kegiatannya. Sedangkan untuk memenuhi kebutuhan hidupnya manusia akan mencari daerah yang sediaan ekologinya mencukupi. Berdasarkan hal tersebut, dan membandingkan kondisi geografis di Bojonegoro dengan di Tuban, tampak bahwa sediaan ekologi di Bojonegoro relatif minim dibandingkan dengan Tuban. Vegetasi yang homogen dengan lembah berbentuk " $U$ " pada morfologi lahan dataran akan dihuni pada waktu yang pendek dibanding dengan daerah yang bermorfologi relatif terjal dengan sediaan ekologi lebih bervariasi dan heterogen baik flora maupun fauna. Hal tersebut tampak pada jejak-jejak hunian berupa bukti arkeologis yang ditemukan dalam ekskavasi gua-gua di Tuban yang lebih bervariasi dalam lapisan tanah relatif tebal, dibandingkan temuan arkeologis di guagua Bojonegoro yang minim dalam lapisan tanah relatif tipis. Selain itu, dengan potensi ekologi yang berbeda, tampaknya hunian gua pada kedua daerah tersebut 
dilakukan secara bergantian dengan masa hunian relatif pendek di Bojonegoro, sedangkan hunian gua-gua di Tuban dilakukan dalam jangka waktu relatif lama.

\section{Pola Komunitas Gua-gua di Pegunungan Kendeng}

Sebagaimana telah diuraikan di atas bahwa kondisi geografis antara Bojonegoro dan Tuban memiliki potensi ekologi dan proses sedimentasi yang berbeda, maka berikut akan dibahas mengenai bukti-bukti arkeologis pada kedua daerah tersebut untuk mengetahui pola komunitas yang diterapkan.

Hasil penelitian yang telah dilakukan pada gua-gua di Bojonegoro menunjukkan bahwa gua-gua yang layak huni cenderung sedikit, sebagian besar gua yang ditemukan adalah tipe sumuran. Sementara itu tanda-tanda aktivitas baik dari fisik maupun keruangan yang tersedia pada gua-gua hunian menunjukkan sangat minim aktivitasnya. Gua-gua yang memiliki indikasi hunian adalah Gua Lawang, Gua Payung, Gua Gampeng, Gua Pawon, dan Gua Grajen. Sementara itu jangka waktu hunian menunjukkan sangat temporer bahkan cenderung insidental. Hal tersebut dibuktikan pada kuantitas temuan artefak yang sangat minim dan tidak didukung dengan lapisan budaya. Dari keenam gua yang pernah dilakukan ekskavasi yaitu pada Gua Lawang 1 dan Gua Kramat (Heekeren, 1972), Gua Pawon (Nurani, 1998/1999), Gua Grajen, Gua Payung, dan Gua Gampeng cukup membuktikan bahwa kelompok gua di Bojonegoro sangat minim aktivitasnya. Kondisi tersebut sangat berbeda dengan potensi budaya yang berhasil ditemukan pada gua-gua di Kabupaten Tuban antara lain di Gua Gedeh dan Gua Kandang (Heekeren, 1972); Gua/Song Prahu (Nitihaminoto, 1980), dan Gua Peturon (Jatmiko, 1997). Potensi budaya di Kabupaten Tuban menunjukkan temuan artefak yang lebih bervariasi baik artefak litik, tulang, maupun cangkang moluska dalam jumlah cukup banyak pada lapisan tanah relatif tebal. Berdasarkan kondisi tersebut, tampak adanya keterkaitan masa hunian antara kelompok gua di Bojonegoro dengan kelompok gua di Tuban. Kemungkinan gua-gua di Bojonegoro dihuni dalam waktu atau musim tertentu, sementara gua-gua di Tuban dihuni pada musim lainnya. Hal tersebut, terbukti dengan kuantitas dan kualitas arkeologis yang berbeda.

Sehubungan dengan konsepsi hunian yang diajukan oleh Black dan Rogers tentang kamp pangkalan dan kamp satelit dan berdasarkan pada potensi arkeologis dan geografis antara Kabupaten Bojonegoro dengan Tuban, maka kemungkinan gua-gua di Tuban merupakan kamp pangkalan, sedangkan gua-gua di Bojonegoro sebagai kamp satelit. Daerah Tuban yang secara geografis dekat pantai dengan sediaan ekologi baik flora maupun fauna darat dan laut yang bervariasi akan dihuni dalam waktu lama, sementara daerah Bojonegoro merupakan daerah dengan morfologi relatif datar dengan lembah berbentuk $U$ menunjukkan sediaan ekologi yang homogen baik flora 
maupun fauna, dihuni dalam waktu relatif pendek. Namun demikian perbedaan sediaan ekologis pada kedua daerah tersebut semuanya dibutuhkan manusia saat itu untuk mempertahankan hidupnya. Hal tersebut menunjukkan pola hunian secara bergilir, di mana gua-gua hunian di Bojonegoro dihuni pada waktu tertentu dengan sediaan ekologi khusus yang tidak terdapat di daerah Tuban, sementara pada waktu yang berbeda, gua-gua di Tuban dihuni dalam jangka waktu panjang. Penjadualan hunian pada kedua daerah tersebut disebabkan oleh sediaan ekologi yang sudah tidak mencukupi lagi, selain itu, faktor musiman juga mempengaruhi pola hunian, di mana daerah Tuban yang terletak dekat pantai pada musim hujan akan mengalami luapan air laut, sehingga gua-gua daerah tersebut tidak dapat dihuni. Sedangkan secara arkeologis hubungan gua-gua hunian kedua daerah tersebut dapat ditunjukkan pada artefaktual dan ekofak cangkang moluska yang ditemukan di gua-gua Bojonegoro yang terletak $50 \mathrm{~km}$ dari pantai. Berdasarkan hal tersebut, tampak bahwa ada interaksi sosial antara komunitas yang menghuni gua-gua di Bojonegoro dengan komunitas gua-gua di Tuban.

\section{Penutup}

Berdasarkan uraian tersebut di atas dapat disimpulkan hal-hal sebagai berikut :

- Kondisi geografi antara Kabupaten Bojonegoro dan Kabupaten Tuban memiliki beberapa perbedaan. Secara geomorfologi, daerah Bojonegoro merupakan lahan relatif datar dengan lembah berbentuk U, sedangkan Daerah Tuban merupakan lahan relatif terjal dengan lembah berbentuk V. Sediaan ekologi daerah Bojonegoro yang lembab menunjukkan sediaan flora dan fauna yang homogen dan terbatas pada waktu tertentu. Sedangkan sediaan ekologi daerah Tuban yang dekat dengan pantai menyediakan flora dan fauna yang lebih bervariasi/heterogen dalam jangka waktu lama.

- Pola hunian gua-gua di Pegunungan Kendeng Utara yang diterapkan menunjukkan adanya kamp pangkalan dan kamp satelit yang dihuni pada waktu-waktu tertentu. Kamp pangkalan yang dihuni dalam waktu lama karena sediaan ekologi sekitar yang heterogen ditunjukkan pada gua-gua daerah Tuban. Hal tersebut ditunjukkan dengan temuan artefaktual baik litik, tulang, maupun cangkang moluska dalam jumlah relatif banyak. Sementara itu, kamp satelit yang dihuni pada waktu relatif pendek dengan sediaan ekologi khusus ditunjukkan pada gua-gua daerah Bojonegoro. Sebagaimana ditunjukkan dalam temuan artefak cangkang moluska dan tulang dalam jumlah relatif sedikit tanpa didukung lapisan budaya. 


\section{KEPUSTAKAAN}

Bettinger, Robert L., 1980, Explanatory / Predictive Models of Hunter - Gatherer Adaptation, in M.B. Scluffer, Advances in Archaeological Methot and Theory, Vol. 3. pp. $189-255$

Chang, K.C., 1968. Settlement in Archaeology, Module in Anthropology, National Press Books, Palo Alto, California.

Glover, Ian C., 1982. Settlement and Mobility Among the Hunter Gathers of Southeast Asia, in P.J.R. Tringham and G.W. Dimbleby, rev., Man Settlement and Urbanism. London : Duckworth p.p. $158-164$.

Heekeren, H.R. van., 1972. Stone Age of Indonesia, VKI, The Hague : Martinus Nijhoff.

Jatmiko, 1996, Laporan Penelitian Arkeologi Eksplorasi Tinggalan Gua-gua Prasejarah Masa Pos-Plestosen di Kabupaten Tuban dan Bojonegoro, Provinsi Jawa Timur. Jakarta : Pusat Penelitian Arkeologi Nasional. Belum diterbitkan.

------, 1997, Laporan Hasil Penelitian Arkeologi Ekskavasi di Situs Gua Peturon (Kabupaten Tuban) dan Gua Lawang (Kabupaten Bojonegoro), Provinsi Jawa Timur. Jakarta : Pusat Penelitian Arkeologi Nasional. Belum diterbitkan.

Mundarjito, 1990, Metode Penelitian Permukiman Arkeologi, Monumen Lembaran Sastra Seri Penerbitan Ilmiah No. 11 Edisi Khusus, Depok : Fakultas Sastra UI, hlm. $19-31$

Nitihaminoto, Goenadi dan Lucas Partanda Koestoro, 1980, Laporan Penelitian Arkeologi Ekskavasi Dander, Bojonegoro, Jawa Timur. Yogyakarta : Balai Arkeologi. Belum diterbitkan.

Nurani, Indah Asikin, 1998/1999, Laporan Penelitian Arkeologi Pola Pemanfaatan Lahan Gua-gua di Kabupaten Bojonegoro, Jawa Timur. Yogyakarta : Balai Arkeologi. Belum diterbitkan. 


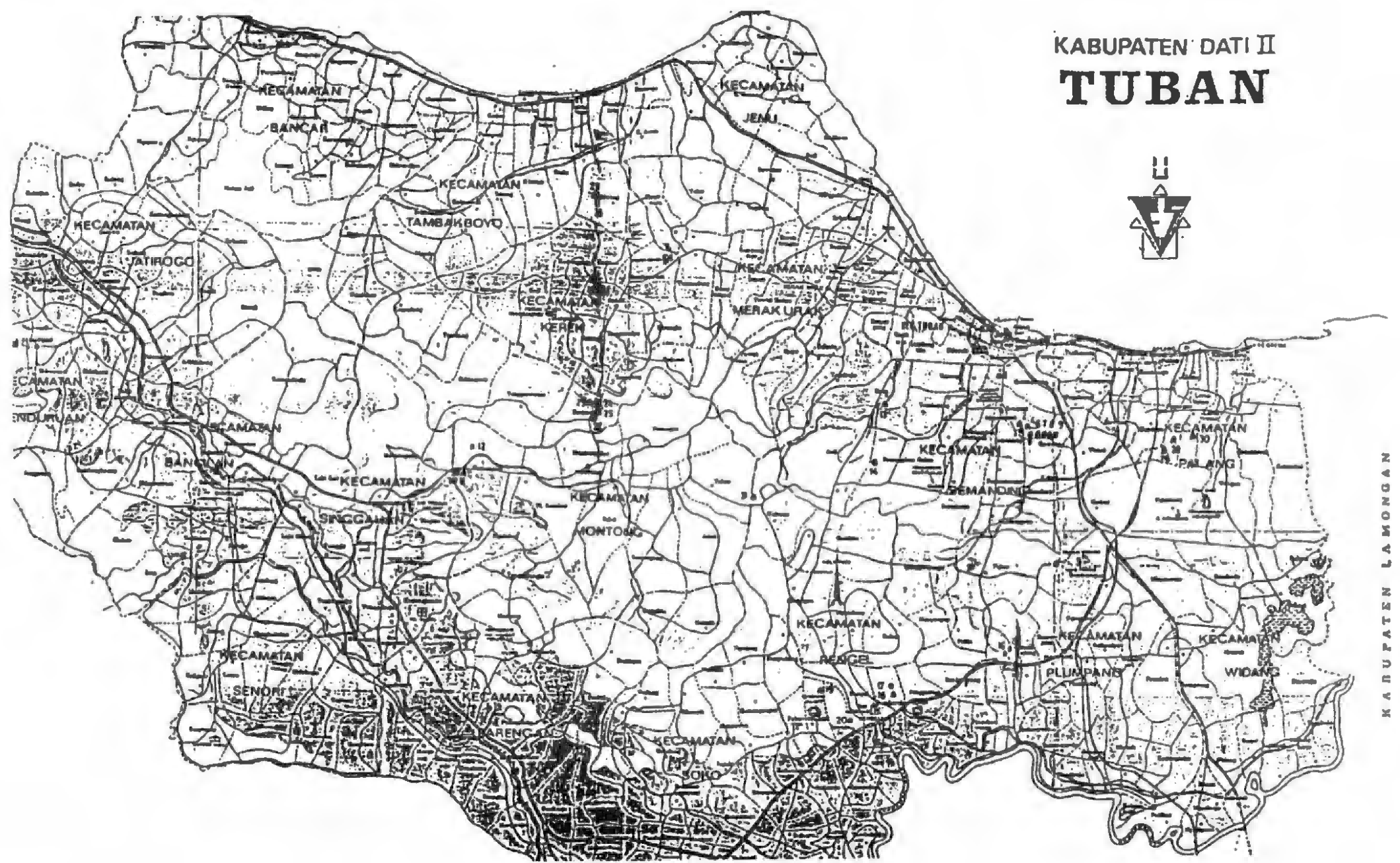




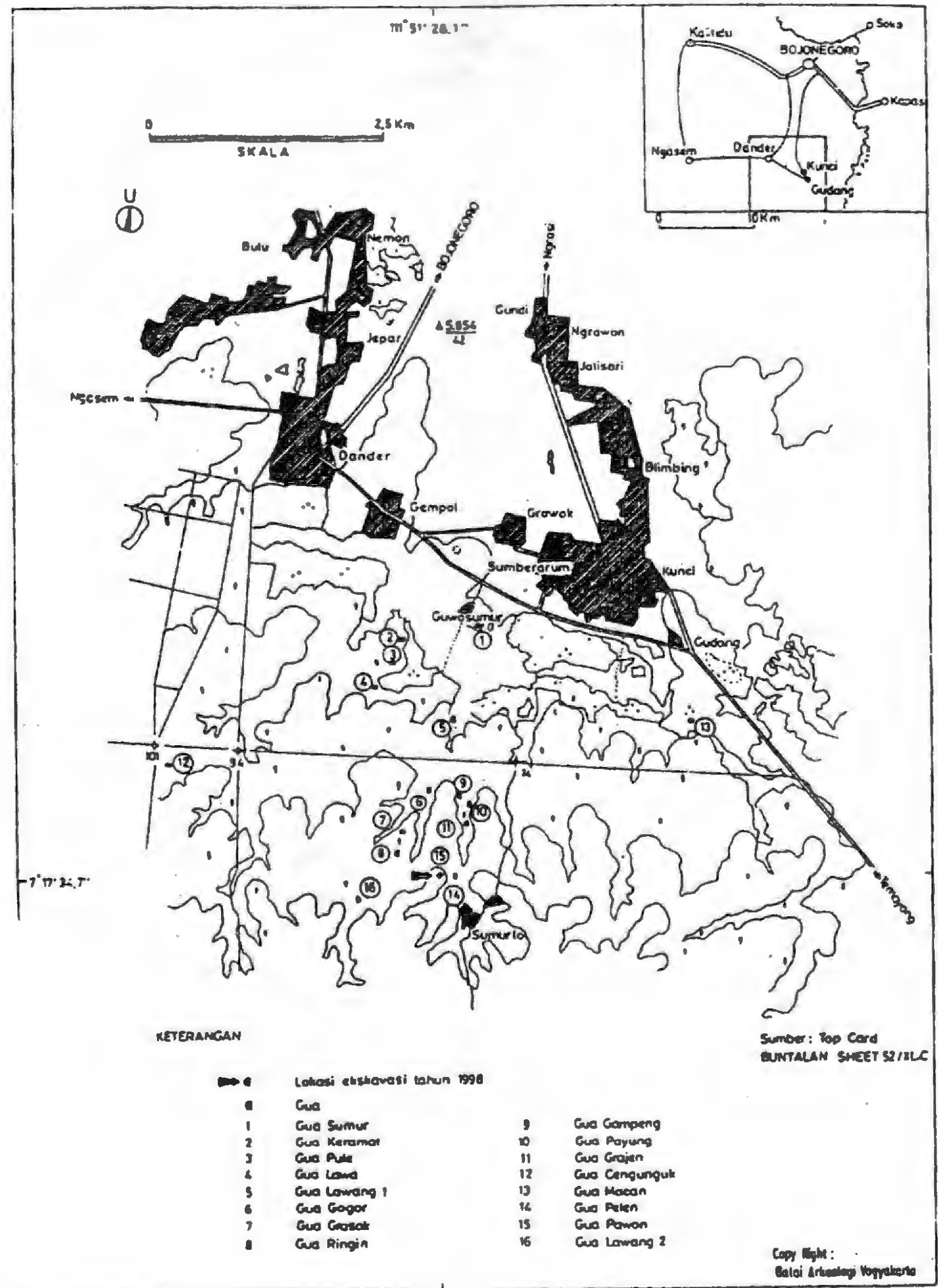

Gambar 2. Pela Oistribusi Gua Pegunungan Kendeng Utara Kab. Bojonegoro 